\title{
Analysis of Teaching Programmes for Interactive Boards
}

\author{
M. Maněnová, M. Skutil, and J. Burgerová
}

\begin{abstract}
Interactive boards became nearly apparent equipment of classes at basic schools. It is a type of modern didactic mean which could increase pupil's motivation, contribute to activation of pupils and enable more vivid presentation of the subject matter. From the viewpoint of the teacher the software is the most important part of interactive board. SmartBoard, ActivInspire and WorkSpace belong to the most used software. We tried to compare these three programmes with the help of comparative analysis from the view of equipment as a whole and separate tools. Simultaneously we added evaluating standpoint of the students - teachers on the elected programmes and their implementation in the practice.
\end{abstract}

Index Terms - Component, formatting, style, styling; insert.

\section{INTRODUCTION}

Thanks to continually developing technique we obtain continuously new didactic means. Today trend is mutual connection of separate means and integration with other technologies (mostly audiovisual and possibilities of computer networks). This group of mutually connected didactic means (in the sense of hardware and software) is simply called multimedia. These means are closely connected with teaching process and have more fundamental role in teaching all the time. The main role of today's teacher is in the first place the choice of suitable means for teaching. It is case of means with which the pedagogue influences the pupils, stimulates them for learning, motives, builds sense and intellectual contact with the subject of teaching to reach the determined aims [1].

\section{THEORETICAL BASIS}

Information and communication technologies (ICT) are constantly more and more progressive with regard to innovation. In consequence to it they could influence educational process. ICT represent a tool which enables easier approach to knowledge from all branches of human activity. Education plays important role in the development of creativity and "innovative potential" [2]. Contemporary young generation has grown up in information society, in spite from their teachers, who come out from "traditional" methods and tools [3].

An example of technologies which enable exploitation of

Manuscript received March 30, 2016; revised September 20, 2016.

Martina Maněnová and Martin Skutil are with the Institute of Primary and Preprimary Education, Faculty of Education, University of Hradec Králové, Czech Republic (e-mail: martina.manenova@uhk.cz, martin.skutil@uhk.cz).

Jana Burgerová is with the Department of Natural Sciences and Technological Disciplines, Faculty of Education, University of Presov, Presov, Slovakia (e-mail: jana.burgerova@unipo.sk). new teaching sources could be IB. The first company which introduced a new product in 1991 - interactive board, was the Canadian company SMART Technologies Inc. with the headquarters in Calgary (Alberta). At the beginning this product was used only for presentation of firms, gradually it showed that its highest potential it has just in schools [4].

In the Czech Republic IB started to be used around 2000. At first their price was very high. Survey of the European Commission was published in 2013, its aim was to find out the up to date condition of technologies application in schools (in total 27 European countries took part in the investigation) Survey of schools: ICT in Education. The Czech Republic took up a position of the first place in exploitation with $61 \%$ (application, use) of IB at least once a week (EU 33\%) [5].

\section{METHODOLOGY}

The research is drafted as a quantitative study aimed at IB, on concrete types of programmes and their possibilities and parameters.

The method of comparative analysis was applied for comparison of the separate tools of selected software for IB. The analysis is based on subjective evaluation of concrete tools. As the fundamental criteria of evaluation was chosen applicability in practice, simplicity and speed of work with the tool, intuitive mastering of separate tools, technical equipment of the tool and correct function

We came out from several viewpoints for the total evaluation of software. At first we aimed at comparison of hardware set by the producer and possibility of optional accessories. In the second phase the separate tools were evaluated from the user's point of view.

\section{A. Aims and Research Question}

The primary aim of the project was comparison of separate tools in the selected types of sofwares.

We aimed at selected tools with which the current userpedagogue meets in practice most often. The secondary aim was to find out how the selected programmes for IB are evaluated by students -teachers from the view of their practical importance.

Two research questions were determined:

1) In what the separate selected programmes differ

2) How the selected IB programmes are evaluated by students-teachers?

\section{B. Research Set}

The programmes SmartBoard, ActivInspire and WorkSpace, which belong to mostly used in educational practice, were selected for comparative analysis.

The research set for fulfilment of the second aim were formed by the students of the branch Teaching for the 1st level of basic school. In total 108 record sheets were processed, 
which were filled in by the responders. The group of responders consisted of the students of 3., 4., and 5. year of master's study who had already greater experience with educational practice and therefore could relevantly evaluate the selected programmes. The choice of research set was intentional.

\section{Research Group}

The research group consists of students in the field of Teaching the first grade in a primary school for the Faculty of Education, University of Hradec Králové. It is therefore a deliberate selection, which is, however, in our opinion, sufficiently representative for the purposes of this investigation. Overall, 371 questionnaires were administrated 298 were filled within the set deadline. Therefore, the return amounted to $80.3 \%$. Out of the participating students, $75.3 \%$ were full-time students and $24.7 \%$ part-time students.

\section{RESEARCH RESULTS}

\section{A. Hardware Equipment}

In Table I the hardware equipment of the selected types of IB is introduced. It could be seen that all three IB support Windows, Mac and Linux operation systems.

If we compare rate of price and hardware equipment of the selected boards, the best place would win IB from Promethean company. The board disposes with the biggest dimensions and distinction of the toutch surface from the compared IB. The surface of the board is made of melamine, which is strongly resistant against mechanical damage. One of the negative is, e.g., big weight for the board.

\begin{tabular}{|c|c|c|c|}
\hline Hardware & InterWrite & SmartBoard & Promethean \\
\hline Years of issue & 2012 & 2013 & 2013 \\
\hline Type & TouchBoard & TouchBoard & TouchBoard \\
\hline Model & EITB2078 & SB 680 & ABV387PRO \\
\hline Price & 1122 EUR & 1584 EUR & 1440 EUR \\
\hline Guarantee & $2 / 5$ years & $2 / 5$ years & $3-5$ years \\
\hline Software & WorkSpace & $\begin{array}{l}\text { SMART } \\
\text { Notebook }\end{array}$ & ActivInspire \\
\hline $\begin{array}{l}\text { Ratio of screen } \\
\text { pages }\end{array}$ & $4: 3$ & $\begin{array}{l}4: 3 \quad \text { with } \\
\text { support } 16: 9, \\
16: 10 \text { a } 4: 5\end{array}$ & $16: 10$ \\
\hline Diagonal & $\begin{array}{l}78 " \quad(198,12 \\
\mathrm{cm})\end{array}$ & 77" (195,6 cm) & $87 "(219,6 \mathrm{~cm})$ \\
\hline Dimension & $\begin{array}{l}177,5 \times 132,4 \\
\mathrm{~cm}\end{array}$ & $165,7 \times 125,7$ & $210,5 \times 132,9$ \\
\hline Weight & $18,8 \mathrm{~kg}$ & $13,6 \mathrm{~kg}$ & $27 \mathrm{~kg}$ \\
\hline $\begin{array}{l}\text { Differentiation } \\
\text { toutch of the } \\
\text { surface }\end{array}$ & $8000 \times 8000$ & $4000 \times 4000$ & $14600 \times 9200$ \\
\hline Feeding & USB & USB & USB \\
\hline Projector & Hitachi & Unifi 45 & Hitachi \\
\hline $\begin{array}{l}\text { Integrated } \\
\text { reproductors }\end{array}$ & - & yes & yes \\
\hline $\begin{array}{l}\text { Storage } \\
\text { temperature }\end{array}$ & $\begin{array}{l}-40^{\circ} \mathrm{C} \\
70^{\circ} \mathrm{C}\end{array}$ & $-40^{\circ} \mathrm{C}-50^{\circ} \mathrm{C}$ & $-20^{\circ} \mathrm{C}-70^{\circ} \mathrm{C}$ \\
\hline Supporting OS & $\begin{array}{l}\text { Windows, } \\
\text { Mac, Linux }\end{array}$ & $\begin{array}{l}\text { Windows, } \\
\text { Mac, Linux }\end{array}$ & $\begin{array}{l}\text { Windows, Mac, } \\
\text { Linux }\end{array}$ \\
\hline $\begin{array}{l}\text { Connection to } \\
\text { PC }\end{array}$ & USB & USB & USB \\
\hline $\begin{array}{l}\text { Digitalisation } \\
\text { technology }\end{array}$ & infrared & resistance & $\begin{array}{l}\text { passive } \\
\text { electromagnetic }\end{array}$ \\
\hline
\end{tabular}

\section{B. Basic Equipment}

When buying IB a parcel with basic accessories is included in the price. In Table II the list of these basic elements which are delivered together with IB is introduced. It is visible from the table that the best support is provided by SmartBoard firm.

TABLE II: BASIC EQUIPMENT OF IB

\begin{tabular}{llll}
\hline \hline Basic equipment & InterWriter & SmartBoard & Promethean \\
\hline Software DVD & yes & yes & yes \\
Pens & 4 & 4 & 2 \\
Userś manual & yes & yes & yes \\
USB cable & yes & yes & yes \\
Erase sponge & yes & yes & - \\
Remote control & yes & yes & yes \\
Essembly material & yes & yes & yes \\
\hline \hline
\end{tabular}

\begin{tabular}{llll}
\multicolumn{4}{c}{ TABLE III: OPTIONAL ACCESSORIES OF IB } \\
\hline \hline InterWrite & SmartBoard & Promethean \\
\hline Movable rack & yes & yes & yes \\
Sounding & yes & yes & yes \\
Bluetooth & yes & yes & yes \\
Wireless tablet & yes & yes & yes \\
Spare pens & yes & yes & yes \\
Pointer & yes & yes & yes \\
Vizualizer & yes & yes & yes \\
\hline \hline
\end{tabular}

TABLE IV: SELECTED TOOLS FOR SOFTWARE ANALYSIS

\begin{tabular}{|c|c|c|c|}
\hline Selected tools & WorkSpace & $\begin{array}{l}\text { Smart } \\
\text { Notebook }\end{array}$ & ActivInspire \\
\hline Main panel & yes & yes & yes \\
\hline $\begin{array}{l}\text { Annotation of working } \\
\text { surface }\end{array}$ & yes & - & yes \\
\hline $\begin{array}{l}\text { Regime of office, to } \\
\text { import }\end{array}$ & yes & yes & yes \\
\hline Pen & yes & yes & yes \\
\hline Point-up pen & yes & yes & yes \\
\hline Multicolour pen & yes & yes & - \\
\hline Piture pen & yes & yes & - \\
\hline Shapes & yes & yes & yes \\
\hline Drawn shapes by hand & yes & yes & yes \\
\hline Line & yes & yes & yes \\
\hline Text & yes & yes & yes \\
\hline $\begin{array}{l}\text { Vacant page without } \\
\text { filling }\end{array}$ & yes & yes & yes \\
\hline $\begin{array}{l}\text { To create the page of } \\
\text { calendar }\end{array}$ & yes & - & - \\
\hline Page withgrid & yes & - & yes \\
\hline $\begin{array}{l}\text { To create the page of } \\
\text { picture }\end{array}$ & yes & yes & yes \\
\hline $\begin{array}{l}\text { To create duplicite } \\
\text { page }\end{array}$ & yes & yes & yes \\
\hline Light cone & yes & yes & yes \\
\hline Catch & yes & yes & yes \\
\hline $\begin{array}{l}\text { Recognition of text } \\
\text { written by hand }\end{array}$ & yes & yes & yes \\
\hline $\begin{array}{l}\text { Exam view, SMART } \\
\text { response }\end{array}$ & yes & yes & yes \\
\hline Page with pattern & - & yes & - \\
\hline Ruler & yes & yes & yes \\
\hline Triangle & yes & yes & yes \\
\hline Protractor & yes & yes & yes \\
\hline Pair of compasses & yes & yes & yes \\
\hline References & yes & yes & yes \\
\hline Page with filling & yes & yes & yes \\
\hline Page with crossing & yes & yes & yes \\
\hline Screen & yes & yes & yes \\
\hline
\end{tabular}

There is also, with IB, an offer of enlarging accessories. When buying these optional accessories it is necessary to compare their real contribution and costs. The producers 
provide nearly the same enlarging equipment. In Table III the products with which we can meet in practice most often are selected.

\section{Comparative Analysis of the Tools}

The tools which we compared at separate types of software were selected on the basis of the frequency of applicability in practice. In Table IV are given the result of the analysis.

\section{Final Evaluation of Comparative Analysis}

In below introduced Table $\mathrm{V}$ are the selected tools of separate programmes for IB evaluated from the viewpoint of their friendliness. This evaluation was carried out by 35 students of teaching for the 1st degree level of basic school. They were asked for independent judgment of the selected programmes in the framework of research. Before judgment they did not have experience with work with IB and they went through the course aimed at general principles with IB. Then the selected programmes were introduced to them.

TABLE V: MEAN EVALUATING OF TOOLS By THE STUDENTS

\begin{tabular}{|c|c|c|c|}
\hline & WorkSpace & $\begin{array}{l}\text { Smart } \\
\text { Notebook }\end{array}$ & $\begin{array}{l}\text { ActivInspir } \\
\text { e }\end{array}$ \\
\hline Main panel & + & +++ & ++ \\
\hline $\begin{array}{l}\text { Annotation of working } \\
\text { surface }\end{array}$ & ++ & + & +++ \\
\hline Import, regime office & +++ & ++ & ++ \\
\hline Pen & +++ & ++ & + \\
\hline Point-up pen & +++ & + & ++ \\
\hline Multicolour pen & +++ & +++ & + \\
\hline Shapes & +++ & ++ & + \\
\hline Distinguishing as a shape & + & +++ & +++ \\
\hline Line & + & +++ & ++ \\
\hline Text & ++ & +++ & +++ \\
\hline Eguation & + & +++ & ++ \\
\hline Gum & ++ & +++ & + \\
\hline $\begin{array}{l}\text { Vacant page without } \\
\text { filling }\end{array}$ & ++ & +++ & +++ \\
\hline Page of calendar & +++ & + & + \\
\hline Page with grit & ++ & + & +++ \\
\hline $\begin{array}{l}\text { Creation of the page of } \\
\text { picture }\end{array}$ & ++ & + & +++ \\
\hline $\begin{array}{l}\text { To create the duplicate } \\
\text { page }\end{array}$ & +++ & +++ & +++ \\
\hline Light cone & +++ & ++ & + \\
\hline To catch & + & ++ & +++ \\
\hline $\begin{array}{l}\text { Recognition of text written } \\
\text { by hand }\end{array}$ & + & +++ & ++ \\
\hline $\begin{array}{l}\text { Exam view, SMART } \\
\text { response }\end{array}$ & + & ++ & +++ \\
\hline Page with pattern & + & +++ & + \\
\hline Ruler & + & ++ & +++ \\
\hline Triangle & + & +++ & ++ \\
\hline Protractor & + & +++ & ++ \\
\hline Pair of compasses & + & ++ & +++ \\
\hline References & + & +++ & +++ \\
\hline Page with filling & + & +++ & ++ \\
\hline Page with crossing & +++ & + & ++ \\
\hline Screen & +++ & ++ & ++ \\
\hline Total sum & 57 & 71 & 67 \\
\hline
\end{tabular}

The students worked with separate tools in the framework of forming beforehand defined materials. Each student created in each programme one activity (the activities were unambiguously defined, for possibility of mutual comparison of all used tools). Consequently the students evaluated the work with separate tools (one + - the worst, three + - the best). The mean results of evaluation are given in Table $\mathrm{V}$. It follows from the table that the best evaluation won SmartNotebook programme.

\section{CONCLUSION}

Our findings show that the highest plus evaluation obtained SmartBoard programme. From the viewpoint of the user is its environment most pleasant and most clearly organized. All tools which it contains work as they should work, this could not be said, e.g. about WorkSpace programme. SmartBoard programme is very intuitive so it should not cause any problems even to beginning users. In case we would be concerned with all tools, which contain selected programmes and compare them, we would find out that WorkSpace programme contains significantly less of them than the remaining two programmes. What concerns of number of tools, the softwares ActivInspire and SmartBoard are highly balanced. ActivInspire contains admittedly tools of higher quality from the view of possibility of adjusting, but for regular (current) user is their adjustment relative complicated matter.

SmartBoard in contrast to the other selected boards contains in its basis 4 coloured styluses which make easier the work with the tool Pen. We do not need to change the colour of the separate pens, it is sufficient to take the colour pen from appropriate compartment. It is necessary to put the pen back to the compartment from which we took it. If, e.g., we put into the compartment for red pen stylus of different colour and take it up again, the stylus recognizes that the red pen is active and red colour will be used, so not the real colour of the pen.

Further positiveness of the board is possibility of manipulation with help of stylus or even by user's finger. The board supports Gest function, what makes the work with the objects easier (rotating, distancing, putting further away, approaching, etc.)

As a disadvantage we consider the fact that more users could not work with the board at the same time. If we want a board on which could work two users at the same time, then it is more suitable to choose the board from Promethean producer. In this case we must count with higher demand on training of the user, who will work with ActivInspire programme.

What concerns of hardware equipment the board is visually lightest, supports the most different ratio of pages but is the most expensive. How it could be seen in table No. 2, SMART Technologies producer provides wide-range of basic accessories and that reflects in higher purchase cost of the board.

At the beginning of the research, we asked ourselves, what is the view of future teachers is regarding SMART technologies. Based on the findings, we can conclude that the students have a more positive attitude towards the use of 
SMART technologies, they are most familiar with the interactive whiteboard. Although their readiness is not high. Here we see reserves in terms of the preparation of future teachers, as well as in the field of research that can help to better uncover the deficiencies in teacher education.

\section{ACKNOWLEDGMENT}

This paper was developed with the support of the Faculty of Education, University of Hradec Králové.

\section{REFERENCES}

[1] V. Rambousek, Technické Výukové Prostředky, Praha: SPN, 1989.

[2] J. Zhao and O. Pablos, "School innovative management model and strategies: the perspective of organizational learning," Information Systems Management, vol. 26, no. 3, pp. 241-251, 2009.

[3] (2013). Survey of Schools: ICT in Education Benchmarking Access, Use and Attitudes to Technology in Europe's Schools. [Online]. Available:

https://ec.europa.eu/digital-single-market/sites/digital-agenda/files/K K-31-13-401-EN-N.pdf

[4] (2007). Smart Technologies, Beginnigs of Idustry. [Online]. Available: http://www.smarttech.com/us/About+SMART/About+SMART/Innov ation/Beginnings+of+an+industry

[5] S. Bennett and L. Lockyer, "A study of teachers' integration of interactive whiteboards into four Australian primary school classrooms," Learning, Media and Technology, vol. 33, no. 4, 289-300, 2008.

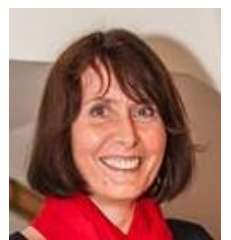

M. Maněnová got the master teacher study programme in Faculty of Education Hradec Králové (physics basic techniques), 2003; the doctoral study programme in Faculty of Science of Matej Bel University of Banska Bystrica, Slovakia (Ph.D.), 2012- Associate professor.

Now she is a lecturer at the Faculty of Education of University Hradec Králové (ICT, Technical Education, Didactics of science) She participated in projects "Evaluation of the modern technologies contributing towards forming and development university students'competences," "Comparative analysis of e-learning system Moodle and WebCT, with a focus on technical and humanities," "Research skills of teachers and students in the use of ICT to primary school" and Erasmus + project "Filpp IT".

M. Maněnová is a member of professional bodies: Czech Statistical Society, Czech Association of Educational Research (belongs to European
Education Research Association) and also member of Czech Education Society. She actively participated in the WSEAS conference EDUTE 2010, ASC 2010, EDU '11.

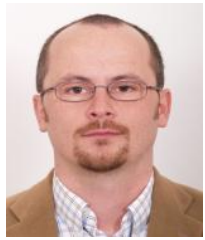

M. Skutil was born in 1978 in Hradec Králové, Czech Republic. He earned the master degree in a field of education at the Faculty of Education, University of Hradec Králové in 2002. After that he moved to the Faculty of Arts, Masaryk University n Brno, where he earned the doctoral degree in a field of education in 2009 .

He works at the Institute of Primary and Preprimary Education, Faculty of Education, University of Hradec Králové in the Czech Republic since 2005. At the present time (since 2009), he is a secretary of the Institute. He cooperates with different foreign institutions. He is also solver and co-solver of many research and development projects. He wrote a book focused on methodology of education research and published many articles, e.g. Maněnová, Martina, Skutil, Martin, Zikl, Pavel. Taking advantage of ITC by teachers at the primary school. Educational technologies (EDUTE'10): proceedings of the 6th WSEAS/IASME international conference. Athens: WSEAS, 2010. and Maněnová, Martina, Skutil, Martin. Topical accesses to teaching students of the study line teaching profession for the 1st level of primary schools: Partial information from research. Problems of Education in 21 st century, 2009, Vol. 13, p. 66-73. His field of interest is General didactics with a view on ICT, Methodology of educational research and Comparative education.

Dr. Skutil is member of Czech Education research association (belongs to European Education Research Association) and also member of Czech Education Society. He presented articles at WSEAS conference and published other articles in European journals. He has been lecturing in different European countries.

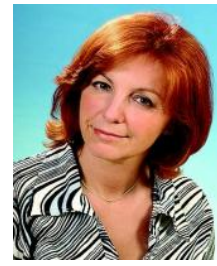

J. Burgerová was born in 1659. Now she is the dean of Faculty of of Education, University of Prešov, Slovakia. Her focus is e-learning, new technology and ICT in Primary and Preprimary education. Selected publications: Burgerová, J., Adamkovičová., M Improve the quality of e-learning education in the conditions of the Faculty of PU in Prešov (2012) and publications with $M$. Maněnová. Burgerová is a member of professional bodies: The Chair of the Scientific Committee of the Conference selected aspects of the quality of education in the PU, Chair of the Programme Committee of the international scientific conference UNINFOS 2011 - PREŠOV 2011 